This item was submitted to Loughborough's Research Repository by the author.

Items in Figshare are protected by copyright, with all rights reserved, unless otherwise indicated.

\title{
A dynamic human capital perspective on corporate opportunity identification
}

PLEASE CITE THE PUBLISHED VERSION

http://dx.doi.org/10.4337/9781785368738.00009

PUBLISHER

(c) Shaker A. Zahra, Donald O. Neubaum and James C. Hayton. Published by Edward Elgar Publishing.

VERSION

AM (Accepted Manuscript)

LICENCE

All Rights Reserved

REPOSITORY RECORD

Hughes, Mathew, Deniz Ucbasaran, and Miranda Lewis. 2016. "A Dynamic Human Capital Perspective on Corporate Opportunity Identification”. Loughborough University. https://hdl.handle.net/2134/24337. 


\author{
Mathew Hughes \\ Durham University Business School, \\ Mill Hill Lane, \\ Durham, DH1 3LB, United Kingdom \\ t: +44 (0) 1913345906 \\ e: mat.hughes@durham.ac.uk
}

\author{
Deniz Ucbasaran \\ Warwick Business School \\ University of Warwick \\ Coventry, CV4 7AL, United Kingdom \\ t: +44 (0)24 76522074 \\ e: deniz.ucbasaran@wbs.ac.uk
}

\author{
Miranda Lewis \\ Warwick Business School \\ University of Warwick \\ Coventry, CV4 7AL, United Kingdom \\ t: +44 (0)24 76522074 \\ e:phd13ml@mail.wbs.ac.uk
}


"First we shape our structures, afterwards they shape us" (Winston Churchill).

\section{Introduction}

Considerable prior research has explored the determinants and performance effects of firm-level entrepreneurship. The emphasis has tended to be on the firm's external environment, strategy, structure and organizational culture as antecedents to corporate entrepreneurship (hereafter, CE) (Zahra et al., 1999; Phan et al., 2009). The outcomes of CE have been linked to economic and strategic gains (Narayanan et al., 2009), with emphasis shifting towards trying to gain an understanding of the non-financial effects of CE in recent years. In particular, CE has been viewed as a means of inducing and cultivating organizational learning that can be used to develop organizational capabilities (Dess et al., 2003). In this chapter we build on and extend both these strands of research by emphasizing the role of the firm's human capital. First, we extend previous work on the antecedents of CE by focusing on the role of human capital as a potentially crucial driver. Second, we argue that the outcomes of CE, particularly in terms of learning, should be viewed in terms of how it will influence the nature and composition of the firm's human capital base. We focus on learning the process of acquiring and integrating new knowledge - because it can help the firm expand its range of strategic choices; improve its ability to continuously build and modify unique capabilities; and prevent its core capabilities from becoming core rigidities (Kang and Snell, 2009).

We propose a dynamic two-way relationship between human capital and CE. Initial stocks of human capital may determine the extent and nature of CE, while CE in turn can result in the modification / development of the firm's human capital base. We also argue that this relationship between human capital and CE will be moderated 
by the organization's entrepreneurial orientation and its internal processes and structures.

Human capital has been heralded as a critical, if not the most important, firm resource which is central to value creation (Pfeffer, 1994; Hitt and Ireland, 2002), particularly in a knowledge-based economic landscape (Grant, 1996; Coff, 1997; Stewart, 1997; Nahapiet and Ghoshal, 1998). Recent multi-level conceptualizations of human capital (Ployhart, Moliterno, 2011; Ployhart et al., 2011; Ployhart et al., 2014) suggest knowledge may reside in many forms and places within the firm, but ultimately it is the individual who must learn (Grant, 1996). Learning, in turn, is influenced by the knowledge and skills embodied in people (i.e., their human capital) (Hatch and Dyer, 2004). The knowledge, skills and learning ability of the firm's employees, and the interaction among them, shapes the firm's human capital and learning capacity. Given the widely acknowledged importance of knowledge and learning to entrepreneurship (Zahra et al., 1999; Shane, 2000), the human element in understanding both the antecedents and outcomes of CE cannot be ignored.

Human capital represents the knowledge, skills, experience and capabilities of individuals (Becker, 1975; Coleman, 1988; Dess et al., 2003; Coff, 2005). Human capital theory posits that knowledge provides individuals with greater cognitive abilities, leading to more productive and efficient activity (Mincer, 1974; Becker, 1975). Indeed, empirical evidence has linked human capital to strategic choices (Finkelstein and Hambrick, 1996), strategy implementation (Miller and Lee, 1999), firm outcomes (Barney and Zajac, 1994; Pfeffer, 1994; Sherer, 1995; Lepak and Snell, 1999; Hitt et al., 2001; Wiklund and Shepherd, 2003; Hatch and Dyer, 2004), and even the economic growth of nations (Field, 2000). From a resource-based perspective, human capital resources are seen as critical for creating and sustaining a 
competitive advantage because they are relatively difficult to imitate due to their intangible and socially complex nature (Barney, 1991; Black and Boal, 1994; McEvily and Chakravarthy, 2002).

Before we proceed further, we must address the thorny issue of what we mean by CE. There are several dimensions and types of corporate level entrepreneurship, for example, internal and external venturing, strategic renewal, and formal and informal corporate entrepreneurship have been extensively documented (Sharma and Chrisman, 1999, Zahra et al., 1999). Our objective in this chapter is not to attempt to integrate and cover all these elements. Rather, we seek to take a broad view of CE that encompasses these views but also represents a view that has received considerable consensus in the area of entrepreneurship. Accordingly, consistent with Shane and Venkataraman (2000), Brown et al. (2001), Ireland et al. (2001) and Zahra (2008), we view CE as involving the identification and exploitation of opportunities for new value creation at the level of the firm. The factors that influence opportunity identification and opportunity exploitation are likely to be different (Shook et al., 2003). To ensure depth of discussion, we focus on one of these stages, namely opportunity identification.

We seek to make the following contributions: First and foremost, we seek to develop a human capital based framework that can aid our understanding of the antecedents and outcomes of corporate opportunity identification. This framework is illustrated in Figure 1. Specifically, we seek to highlight the role of employees and their human capital as a potentially valuable driver of CE (path 1). Further, we explain how one of the outcomes of CE can be the development of its human capital base (path 4). Second, we address calls for an appropriate distinction to be drawn between entrepreneurial orientation (EO) and the identification of entrepreneurial opportunities 
(Zahra et al., 1999; Brown et al., 2001). We argue that a firm's EO moderates the relationship between human capital and opportunity identification by acting as a collective mental model that guides human capital (path 3). Finally, we suggest that the firm's internal environmental structure can also moderate the relationship between human capital and opportunity identification (paths 2 and 5). While previous studies have highlighted the importance of a supportive organizational structure as a means of facilitating CE (e.g., Hornsby et al., 2002) (path 2), we argue here that the organization's structure may have important implications for how human capital is developed and deployed, and thus how learning from CE is facilitated (path 5).

\section{INSERT FIGURE 1 HERE}

The structure of the chapter is as follows. First, we explore the relationship between human capital and corporate opportunity identification. Second, we discuss how a firm's EO can influence this relationship. Third, we identify and discuss a set of firm internal processes and structures that can moderate the relationship between human capital and corporate opportunity identification. Fourth, we highlight that the relationship between human capital and opportunity identification can be a reciprocal one. Therefore, we focus on how experience with corporate opportunity identification can impact on individuals' human capital endowment. Further, we argue that organizational processes, in particular those relating to knowledge articulation and codification, may determine the extent to which experience with opportunity identification improves the value of human capital. Finally, we conclude by discussing implications for empirical testing and identifying areas for future research. 


\section{Human Capital as a Driver of Corporate Opportunity Identification (Path 1)}

Several scholars have acknowledged the importance of human capital to entrepreneurship (Bates, 1995; Gimeno et al., 1997; Chandler and Hanks, 1998; Unger et al., 2011). These studies, however, have generally focused on the relationship between human capital and organizational outcomes (e.g., firm entry or exit) rather than entrepreneurial outcomes (i.e., entrepreneurial behavior such as opportunity identification and pursuit).

Applied to the context of entrepreneurship, human capital theory suggests that if profitable opportunities for new economic activity exist, individuals with more or higher quality human capital should be better at identifying them. At a conceptual level, Hostager et al. (1998) identify a broad array of knowledge and skills that each person brings to the corporate setting that can facilitate corporate entrepreneurship. These include awareness of environmental concepts; knowledge of customer needs and preferences; awareness of technological developments; awareness of current communication and IT to share knowledge and experiences with others; creative thinking skills; prior experience of recognizing, screening and evaluating new opportunities. More recently, studies have found human capital to be positively associated with entrepreneurial opportunity identification and / or pursuit at the level of the individual entrepreneur (Shane, 2000; Davidsson and Honig, 2003; Dimov and Shepherd, 2005; Shepherd and DeTienne, 2005; Ucbasaran et al., 2008, 2009; Bhagavatula et al., 2010). What is less clear from this evidence, however, is how human capital can assist opportunity identification within firms.

The inductive view of opportunity identification suggests that opportunities are available in the environment waiting to be discovered (Alvarez and Barney, 2007; 
Zahra, 2008). Kirzner’s (1973) 'entrepreneurial alertness’ perspective suggests that some individuals (i.e., entrepreneurs) have the ability to see where products (or services) do not currently exist, or where they have unexpectedly emerged as being valuable. Conversely, the deductive view suggests that the individual mind creates opportunities in an imaginative act by combining individual experience, subjective understanding, and current information in a complex associative act (Schumpeter, 1934; Witt, 1998; Zahra, 2008). This second view puts centre stage the role of prior knowledge, cognitive processes and mental connections (Grégoire et al., 2010). Grégoire and Shepherd (2011) found that individual differences in knowledge combined with differences in the nature of the opportunities affect opportunity identification abilities. Irrespective of which view is taken, entrepreneurs with superior human capital profiles may have a wider range of knowledge to draw upon. This knowledge may facilitate opportunity identification. If opportunities are indeed circulating in the environment waiting to be discovered, individuals with superior human capital may have greater knowledge of where to look for an opportunity, when an opportunity is present, or what an opportunity 'looks like'. To recognize an opportunity, an entrepreneur must have prior knowledge that is complementary with the new information, which triggers an entrepreneurial conjecture (Kaish and Gilad, 1991; Shane, 2000). Experience-based knowledge can direct an individual’s attention, expectations and interpretations of market stimuli, thus facilitating the generation of ideas (Gaglio, 1997). Alternatively, if opportunities are imagined or created, entrepreneurs with greater levels of human capital may have more 'ingredients' (Sarasvathy, 2008), intelligence, and imagination to work with to identify / create an opportunity. Experience-based knowledge is considered a necessary factor in the 
creative process in that, alongside domain-specific knowledge, it influences the definition of the appropriate problem space and solution criteria (Amabile, 1990).

Individuals with higher levels of human capital may have greater access to knowledge, which they can use to make assessments, judgements, or decisions surrounding opportunity identification (Mitchell et al., 2002). The logic for this resides in the fact that, ultimately, it is individuals within the firm who are responsible for identifying and pursuing opportunities (Hayton, 2005). As such, it can be argued that the firm's ability to identify opportunities is a function of its human capital. Thus, we propose the following:

Proposition 1a: $\quad$ Firms with a superior human capital base will identify a greater number of opportunities in a given period.

Becker (1993) argues that one of the most influential theoretical concepts in human capital analysis is the distinction between general and specific human capital. Human capital can be viewed as consisting of a hierarchy of skills and knowledge with varying degrees of transferability (for example, across firms) (Castanias and Helfat, 1991). If skills and knowledge are easily transferable across a variety of economic settings they can be regarded as general human capital (e.g., education) (Gimeno et al., 1997). Conversely, if skills and knowledge are less transferable and have a narrower scope of applicability, they are regarded as specific human capital (Becker, 1993). Specific human capital typically encompasses knowledge that is deeper, localized, embedded and invested within particular knowledge domains (Kang and Snell, 2009). Human capital is seen to be most valuable and most inimitable when it 
resides in the environment where it was originally developed (Lepak and Snell, 1999; Hitt et al., 2001) partly because of the tacit knowledge that is embedded within it.

Firm-specific human capital is typically the product of individual learning efforts that can lead to knowledge creation through learning by doing, which in turn, enhances the firm's learning capacity and performance (Hatch and Dyer, 2004). Firmspecific human capital may include knowledge of the internal operations of the firm but also knowledge of customers, suppliers, products, and services within the context of the firm (Gimeno et al., 1997). Indeed, both Shane (2000) and Shepherd and DeTienne (2005) found that when leveraged, this latter type of knowledge led to opportunity identification.

Alongside firm-specific human capital, individuals may also possess entrepreneurship-specific human capital. Entrepreneurship-specific human capital is the set of knowledge and skills that individuals can bring to bear to create and exploit market opportunities (Coff, 2005). This is likely to be the result of direct or vicarious entrepreneurial experience (Krueger, 1993; Unger et al., 2011). Prior management and entrepreneurial experience are particularly relevant since they favour opportunity identification (Gruber et al., 2012). At the level of the individual, Ucbasaran et al. (2008) found entrepreneurship-specific human capital to be strongly associated with opportunity identification intensity.

We expect entrepreneurship-specific capital and firm-specific human capital to be particularly important to corporate opportunity identification. While entrepreneurship-specific human capital may facilitate opportunity identification, firm-specific human capital is likely to ensure that those opportunities fit more closely with the firm's existing activities. Unless this fit is ensured, opportunities identified by individuals may not be communicated to key decision makers in the organization. 
Moreover, if firm-specific human capital is low and entrepreneurship-specific human capital high, identified opportunities could be too random resulting in a weak strategic fit with firm competencies. In contrast, if only firm-specific human capital is high, unless the individual has some knowledge of entrepreneurship, they may fail to identify opportunities. If both types of human capital are high, the likelihood that opportunities identified are both numerous and strategically valuable increases. Based on the above discussion, we propose the following:

Proposition 1b: $\quad$ The relationship between human capital and corporate opportunity identification will be strongest when both firm-specific and entrepreneurship-specific human capital is high.

\subsection{Organizational Structures and Processes as Moderators of the Relationship} between Human Capital and Corporate Opportunity Identification (Path 2)

So far we have argued that a firm's human capital base, which embodies the knowledge and skills of its employees, should facilitate corporate opportunity identification. However, while firms may have access to valuable human capital, either through poor design or mismanagement, human resources might not be deployed in a way that achieves adequate strategic impact (Wright et al., 2001; Kaifeng et al., 2012). Because opportunity identification is strongly related to the creation, exchange and combination of knowledge (Nahapiet and Ghoshal, 1996; Zahra, Nielsen and Bogner, 1999), the management of knowledge and human capital becomes important (Kanter, 1985; Hayton, 2005; Bhagavatula et al., 2010; Unger et al., 2011). All things being equal, a firm in possession of superior human capital 
should identify more opportunities than a firm with weaker human capital. However, the internal environment of the firm can dictate how individuals use their human capital for the benefit of the organization. Principally, the internal environment of the firm can either enable individuals to use their human capital in pursuit of opportunity or can impede it. However, while research has identified a set of internal environment conditions sympathetic to corporate entrepreneurship (e.g., Hornsby et al., 1999, 2002; 2009; Hayton, 2005; Kuratko et al., 2005; Ireland et al., 2006a, b; Eddleston et al., 2012), research has not isolated a single best way. Indeed, a general consensus might be that a single structure is not feasible whereas a set of guiding principles informing organizational structure is.

Drawing together several studies, we put forward that an internal environment supportive of the deployment of human capital for corporate entrepreneurship comprises (1) reward incentives and accompanying control structures that support risk taking in pursuit of new opportunities (Hornsby et al., 2002; Hayton, 2005; Monsen et al., 2010); (2) work discretion and autonomy such that managers provide decisionmaking freedom to adjust tasks and undertake new courses of action as and when necessary to pursue organizational goals (Hornsby et al., 2002; Kuratko et al., 2005); (3) a team-based design that enables information exchange and human capital crosspollination by increasing the connectedness of disparate individuals from across the organization (Ireland et al., 2003; Hayton, 2005; Jansen et al., 2006; Kelley et al., 2009); (4) management support and leadership that sets and champions the vision for corporate entrepreneurship in the firm (Hornsby et al., 2002, 2009; Hayton, 2005; Ireland et al., 2009); and (5) availability of adequate resources and time for individuals to pursue environmental scanning, opportunity identification, and corporate entrepreneurship (Hornsby et al., 2002, 2009; Kuratko et al., 2005; 
Shepherd et al., 2007). These lead organizational structures, processes, and practices are summarized in Figure 2. It should be noted however, that while we present these conditions as independent in our diagrammatic representation, in practice we expect interactions and interdependences to exist among them. For the sake of brevity, we will concentrate our discussion on individual conditions for the most part.

\section{INSERT FIGURE 2 HERE}

Human resource management practices geared towards CE require decentralization of authority, participation in decision making, cooperation, avoidance of bureaucracy to encourage and enable risk taking and creativity to take place (Luchsinger and Bagby, 1987). For employees to behave entrepreneurially, they must first be sufficiently motivated to want to identify opportunities (Hayton, 2005). Intrinsic and extrinsic rewards may motivate employees but the control systems that accompany performance management are equally important. Put simply, the performance context shapes and constrains the behavior that individuals will perceive as valued by their organizations (Griffin et al., 2007).

Sykes (1992) argues that the challenge, autonomy, responsibility and status associated with engaging in a successful venture should be enough reward in itself. Extrinsic rewards (i.e., compensation) can further encourage entrepreneurial behavior (Balkin et al., 2000; Chandler et al., 2000) when used in relation to entrepreneurial objectives because they specify directly the behavior that managers wish to see repeated (Morris et al., 2008; Ireland et al., 2009). These studies suggest that organizational practices such as compensation designed to reward investments not outcomes may ensure human capital is deployed in a way that encourages corporate 
opportunity identification. Barringer and Bluedorn (1999) support such a thesis in their discovery that financial controls can harm corporate entrepreneurship as they orient individuals towards the 'bottom line' at the expense of longer term, and more strategic, entrepreneurial outcomes. Emphasis on longer-term rewards in which the appraisal and reward systems account directly for entrepreneurship and are communicated clearly should foster a positive environment for corporate opportunity identification (Ireland et al., 2006a, b). Importantly, such reward and control systems can consciously direct the deployment of human capital in pursuit of organizationallydesired outcomes (Griffin et al., 2007; Hayton, 2005).

Providing employees with autonomy and work discretion may also serve to motivate them to identify opportunities. Indeed, several studies have highlighted the positive relationship between autonomy / discretion and entrepreneurial activity (Burgelman, 1983; Lumpkin and Dess, 1996). Providing work discretion and autonomy to employees reduces the rigidity of tasks and enables individuals to adjust daily activities as they discover new and better ways of doing things (Hayton, 2005; Luchsinger and Bagby, 1987). Work discretion and autonomy then enable individuals to explore new avenues, or opportunities, as they emerge with the implication that such discoveries can be explored in greater depth. In turn, as individuals use their human capital to understand the meaning of emerging opportunities to the corporate context, these individuals are exposed to issues of corporate value and wealth creation they would otherwise be unaware of (e.g., Hornsby et al., 2009). In time the individual will increase their understanding of the business in a way that helps them to identify more and more meaningful opportunities for the firm.

Hayton (2005) proposes that greater autonomy broadens the scope for discretionary behaviors which themselves can have a positive influence on the 
formation of trust and social capital among individuals in the firm. Social capital can ensure that human capital is deployed for corporate opportunity identification, by enabling the sharing of insight, knowledge and mental models (Kang and Snell, 2009).

Organizational structures and practices that promote information exchange may also facilitate opportunity identification as a result. Designing an organizational structure that promotes high levels of communication and cross-functional integration helps to facilitate the exchange of tacit and codified knowledge (Hayton, 2005). Cross-functionality has been found to encourage information exchange (Krohmer et al., 2002) and productive cooperation (Sarin and Mahajan, 2001). Ireland et al. (2003) posit that such boundary spanning exposes individuals to unrelated matrices of knowledge that cross-pollinate human capital in such a way that novel and more comprehensive entrepreneurial behavior should emerge. In turn, deploying a teambased design that facilitates cross-functional linkages and / or encouraging intra-firm networking (Kelley et al., 2009) should promote opportunity identification.

Individuals can achieve flashes of insight but greater exploration of novel opportunities is supported when knowledge from across the firm comes together. Connectedness facilitates the coming together of human capital to synthesize new ideas, views, and thoughts leading to the identification of corporate entrepreneurial opportunities. Accordingly, Jones et al. (1995) argue that entrepreneurial firms tend to make more systematic investments in group skills and socialization. Group skills enhance the quality of interactions among individuals, while socialization helps build common ground and shared understanding, particularly among employees from different functional areas (Nonaka and Takeuchi, 1995). It is not surprising, therefore, that studies have found cross-functional teams to be associated with innovation 
among other positive entrepreneurial outcomes (Hornsby et al., 1999; Sethi et al., 2001).

To encourage individuals to leverage their human capital in pursuit of opportunity identification, they must perceive that management support such endeavours (Eisenberger et al., 1990; Hornsby et al., 1999, 2002, 2009; Chandler et al., 2000; Hayton, 2005). Support can take several forms including championing innovative ideas, encouraging participation in entrepreneurial activities (Hornsby et al., 2002), investments in human capital (Hitt et al., 2001), providing necessary resources or expertise to projects (Kuratko et al., 2005), tolerating risky decisions even if negative outcomes result (Burgelman, 1983; Stopford and Baden-Fuller, 1994), and institutionalizing entrepreneurial activity (Hornsby et al., 2002). Hayton (2005) proposes that perceived organizational support improves the social exchange relationship between an individual and the organization. Recent propositions, however, suggest that the extent to which these benefits materialize may depend on the 'proximity' of managers to their employees (Hornsby et al., 2009). Managers that are distant from employees will likely have weaker social exchange relationships with their staff such that the social capital between them may not be sufficient to benefit corporate entrepreneurship.

Hitt and Ireland (2002) also emphasize the need for strategic leaders to continuously evaluate, change, configure, and leverage human and social capital in the firm to fuel entrepreneurial behavior. Leadership is therefore critical to corporate entrepreneurship (Dess et al., 2003). Leaders play an important role in securing a collective backing for organizational efforts. This requires leaders to articulate a vision for the organization, gain acceptance of that vision, and create congruence between the vision and followers' self-interests (Dess et al., 2003; Ireland et al., 
2009). An openness and willingness to listen are then vital to encourage empowered proactive action in an effort to realize the organization's vision (Morrison and Phelps, 1999). Under such conditions, top management support and leadership should create the requisite impetus and momentum to direct human capital efforts towards corporate opportunity identification.

Top-managers' support for entrepreneurial behavior also includes the organization-wide provision of the resources people need to undertake entrepreneurial actions (Kuratko et al., 2005; Hornsby et al., 2009). Resource slack offers employees the chance to experiment with new ideas and alternatives that may yield valuable new opportunities for the firm. In time, the confluence of human capital and organizational resources can shape a unique firm capability for opportunity identification (Ireland et al., 2009). But, such processes depend on time being available to do so. Managers that evaluate workloads to ensure that individuals and groups have ample time to pursue new avenues of investigation in the course of their work are creating an environment that enables individuals to take full advantage of a team-based design and an information-rich organizational context (e.g., Kuratko et al., 2005; Hornsby et al., 2009). Together, resource and time availability should enable individuals to use their human capital in ways that enable them to identify an increasing number of entrepreneurial opportunities.

The above discussion suggests that the firm's internal environment must be supportive of the behaviors deemed desirable by the organization. In the absence of a supportive environment, individuals may be insufficiently motivated or unable to deploy their human capital to identify opportunities. Poor management support and excessive interference within a structure that rewards caution and penalizes failure will inevitably cause employees to behave conservatively. In contrast, management 
that support entrepreneurial activity within a favorable control regime; facilitate discretion and information sharing; and encourage teamwork are more likely to engender an internal environment that promotes entrepreneurial activity. These enabling forces may work synergistically (e.g., Hayton, 2005). Based on this discussion, we offer the following proposition:

Proposition 2: Firm structures, processes, and practices will moderate the relationship between human capital and corporate opportunity identification.

2.2 Entrepreneurial Orientation (EO) as a Moderator of the Relationship between Human Capital and Corporate Opportunity Identification (Path 3)

The nature of the relationship between human capital and corporate opportunity identification is likely to be moderated by the EO of the organization. While numerous definitions and similar concepts exist, EO can be defined as the methods, practices, and decision-making styles used within organizations to act entrepreneurially (Lumpkin and Dess, 1996). Together these represent the 'mindset' of the firm. The mindset associated with EO encourages a predisposition to act creatively and engage in innovation, to tolerate and take risks, and to proactively seek out, identify and seize opportunities for wealth creation (Lumpkin and Dess, 1996; Miller, 1983; Covin, Wales, 2012). Scholars have not only looked into the macroeconomic and cultural drivers of EO (Saeed et al., 2014) but also into firm-level determinants. While EO has been repeatedly associated with superior firm performance, studies have recently sought to disentangle how such rewards are achieved (Stam and Elfring, 2008) with recent emphasis placed on issues internal to 
the organization (De Clercq et al., 2010) and a specific focus on internal capabilities (Chaston, Sadler-Smith, 2012), heterogeneity of the distribution of EO within the firm (Wales et al., 2011) and organizational learning (Real et al., 2014).

An EO can be viewed as representing one of the organization's knowledge structures ${ }^{1}$. Knowledge structures serve several functions relating to the interpretation and assimilation of new information, memory of old information and making inferences about missing information (Fiske and Taylor, 1991; Walsh, 1995). Specifically, knowledge structures help direct attention, guide information processing and reasoning, and cognitively orders an information-laden environment in a way that enables subsequent interpretation and action for any specific event, real or imagined (Gaglio and Katz, 2001). Collective knowledge structures are said to exist when several individuals are brought together and behave according to certain principles which then become embedded as organizational knowledge structures (Walsh, 1995). An EO can be considered as an organization-level knowledge structure because it represents the mindset of firms engaged in the pursuit of new venture opportunities (Lumpkin and Dess, 2005). Consequently, since an EO guides how people think, interpret and act on information, it can be useful to think of it in such terms when considering the relationship between human capital and corporate opportunity identification.

An EO can act as a mechanism guiding the deployment of the organization's human capital pool. In the context of environmental change, those with the necessary human capital and entrepreneurial intentions (Bird, 1992; Krueger, 1993; Krueger and Brazeal, 1994) are more likely to see and cognitively understand new opportunities whereas most others are concerned with protecting themselves from emerging threats

\footnotetext{
${ }^{1}$ While we choose to use the term 'knowledge structures', the same or similar concepts are known by various other terms such as scripts (referring to an action sequence), schema (relating to the memory of a specific episode), and mental models (a generic term but which implies process).
} 
and changes resulting from the uncertainty associated with environmental change. In the absence of intentions, action is unlikely (Krueger, 2000). Intentions, and therefore the likelihood of action, are heightened when the decision-maker perceives a course of action as being feasible (i.e., within their competence and control), desirable, and supported by social norms (Ajzen, 1991). While human capital is likely to have a direct effect on perceived feasibility, the organization's EO may influence the desirability of a course of action and the extent to which it is consistent with social norms within the organization (Hornsby et al., 2002, Kuratko et al., 2005; De Clercq et al., 2010).

Even if an individual possesses the human capital necessary to identify an opportunity, he or she may fail to do so because of an inability to see new means-ends relationships (Shane and Venkataraman, 2000). By emphasizing risk-taking, innovativeness and proactiveness as desirable organizational practices and norms, an EO may ensure that human capital is deployed to facilitate opportunity identification. It is not surprising then that EO is positively associated with superior information acquisition and information utilization (Keh et al., 2007). EO shapes the behavioral context in which people deploy their human capital. As individuals behave entrepreneurially with and among each other, the resulting social exchanges can encourage new configurations, combinations, and bundles of human capital to form (e.g., De Luca and Atuahene-Gima, 2007), which can then encourage greater entrepreneurial opportunity identification to take place (e.g., De Clercq et al., 2010).

Thus, a firm with a strong EO should identify increasingly more corporate opportunities. This is because EO, like a knowledge structure, acts as a filter for processing and interpreting information and environmental changes with the 'strategic intent' (Hamel and Prahalad, 1989) of identifying opportunities. While superior 
human capital may induce opportunity identification, unless the firm is willing to grasp and enthusiastically pursue these opportunities, then the human capital is likely to go under-utilized (Wiklund and Shepherd, 2003). Without an EO to guide them, employees in an organization are unlikely to combine and use knowledge in novel ways, which can result in myopia. Indeed, people can suffer from myopia because the lenses they use to interpret and apply knowledge are restricted (Miller, 2002). EO can help overcome such myopia because its emphasis on risk-taking, creativity and proactiveness is designed to help people to understand markets better by viewing them in different ways, and broaden their thinking and creative evaluation of possibilities. This argument is supported by recent studies which demonstrate that the relationship between a firm's market orientation (the extent to which it collects and leverages market intelligence organization-wide) and firm performance (Bhuian et al., 2005) and product innovation (Atuahene-Gima and Ko, 2001; Pérez-Luño et al., 2011) improves under the presence of EO.

Overall, we propose that even if individuals have the necessary skills (i.e. human capital) to identify opportunities for the organization, an EO is needed to ensure that the human capital is applied productively and generates actions that will be deemed feasible, desirable and socially acceptable. On the basis of our discussion, we offer the following proposition:

Proposition 3: An entrepreneurial orientation will positively moderate the relationship between human capital and corporate opportunity identification. 


\section{The Dynamic Nature of the Relationship between Human Capital and}

\section{Corporate Opportunity Identification (Path 4)}

So far, we have focused on how human capital can impact on entrepreneurship (e.g., opportunity identification). We argue, however, that the relationship between human capital and entrepreneurship does not end here. The identification and exploitation of entrepreneurial opportunities offers an opportunity for human capital to be developed and modified via learning. Recent articles have suggested that among the outcomes of corporate entrepreneurship, attention should be directed towards new knowledge creation and learning (Dess et al., 2003; Zhao et al., 2011; Simsek, Heavey, 2011; Kreiser, 2011). Accordingly, in this section, we focus on this process.

As intimated earlier, human capital can be viewed as comprising the knowledge, experiences, and (cognitive) skills of the individual. One of the key drivers of human capital development is experience (Unger et al., 2011). For example, prior experience in a particular domain is used as a common proxy for human capital. Similarly, experiences of corporate opportunity identification may help build entrepreneurship-specific human capital. Simsek and Heavey (2011) find that corporate entrepreneurship contributes to the development of the firm's knowledgebased capital both in terms of human capital, social capital and organizational capital. Dess et al., (2003) argue that corporate entrepreneurship can lead to the creation of various types of new knowledge. This knowledge is ultimately likely to be embodied in individuals. Nahapiet and Ghoshal (1996) argue that new knowledge is created through "exchange and combination”. Exchange occurs when knowledge held by one party is transferred to another. Combination occurs when new information is combined with existing knowledge. Since opportunity identification is likely to be the result of both exchange and combination, it offers opportunities for new knowledge to 
be created, which in turn modifies the human capital base of the organization. This approach is based on the implicit assumption that individuals can effectively learn from experience. Learning is "the process whereby knowledge is created through the transformation of experience” (Kolb, 1984:41). For learning to occur there must be an opportunity to learn (McCauley et al., 1994). Novel situations, such as opportunity identification, create opportunities for learning because they set the stage for questioning held views and beliefs (Louis and Sutton, 1991; Dess et al., 2003). Thus:

Proposition 4: Experiences with corporate opportunity identification will increase the quality of an organization's human capital base.

\subsection{Organizational Structures and Processes as Moderators of the Relationship} between Corporate Opportunity Identification and Human Capital (Path 5)

Despite the above proposition, the extent to which experience with corporate opportunity identification can create new knowledge and improve human capital likely depends on individuals being sufficiently motivated to learn (McCauley et al., 1994) and the quality of learning from the corporate opportunity identification experience (Corbett, 2007).

The motivation to learn may stem from the desire to close the gap between the actual and desired level of job competency (e.g., get to grips with a new technology); the discomfort of a painful situation (e.g., a failed opportunity or competitors having identified a valuable opportunity before the firm did); or the desire to achieve an outcome with a significant reward potential (e.g., develop a better product / service for which there is demand) (McCauley et al., 1994). In the absence of a strong motivation to learn, the quality of learning may be adversely affected because 
individuals are likely to resort to a mode of learning which is semi-automatic based on experience accumulation (Zollo and Winter, 2002). We now elaborate on the quality of learning.

Individuals generally adjust their judgment by learning from feedback about past decisions (i.e., experience) (Bazerman, 1990; Corbett, 2007). Due to delays in feedback and problems with interpretation, however, individuals are prone to errors in their learning. Insofar as the learning from past experience is open to errors and biases, the lessons drawn may turn out to be irrelevant, invalid or even misleading (Zakay et al., 2004). To avoid these problems, individuals require an understanding of what they are doing and why (Neale and Northcraft, 1989). This understanding is likely to be associated with action learning. Action learning focuses on awareness surrounding the actual learning process. It is commonly associated with Argyris and Schön's (1978) concept of “double-loop learning” which involves high levels of reflection. It requires continuously assessing whether there is a misalignment between goals and strategies. Action learning involves not only the recognition of such a mismatch but also a willingness to accept it and take corrective action. This type of learning is deemed the most desirable in terms of generating and sustaining competitive advantage. It follows that the impact of experience on the value of human capital is likely to be greatest when action learning is adopted. Unfortunately, in the absence of intervening factors, it is probably the least likely mode of learning to be adopted (discussed below).

Faced with interpreting a particular experience, the motivation to learn and the quality of learning from that experience may be a function of the structures and processes within the firm that determine its absorptive capacity. Absorptive capacity is formed by the structures, practices, and processes within the firm that enable (or 
otherwise) the assimilation, transformation, and leveraging of learning from past experiences to modify existing knowledge and/or create new insights (Lichtenthaler, 2009). Put simply, firm design can constrain the absorptive capacity of the firm and impede individual learning (Zahra et al., 2009). Although the concept of absorptive capacity is normally associated with externally generated knowledge (Lichtenthaler and Lichtenthaler, 2009; Zahra et al., 2009), recent treatments in entrepreneurship research have associated it with the extent to which organizational members learn from past experiences encountered within the firm (Corbett, 2007) and to the development of entrepreneurial orientation and entrepreneurial behaviour within the firm (Wales et al., 2013; Engelen et al., 2014; Garciá-Morales et al., 2014).

Organizations need to develop effective organizational processes that enable employees to come to grips with the meaning and potential implications of knowledge emerging from CE activities (Crossan et al., 1999; Zahra, Nielsen and Bogner, 1999). Higher levels of knowledge sharing have a stronger relationship with EO (De Clercq et al., 2013). The motivation to learn and therefore the quality of learning from an experience may be strongly influenced by organizational practices and structures (introduced and discussed in section 2.1). Lepak and Snell (1999) and Kang and Snell (2009) argue that training, career development and mentoring programs, and pay systems can be designed to encourage learning. For example, developmental performance appraisal systems can be used to ensure that employees receive continued, timely and useful feedback (Snell and Dean, 1992; Griffin et al., 2007). Further, the design of intrinsic or extrinsic reward systems may motivate individuals to learn and develop their human capital. Performance appraisals that contain performance- and merit-based compensation, subsequent training, and continuing internal communication have been found to stimulate employees' willingness and 
ability to learn (Minbaeva et al., 2003). Training programmes generated from developmental performance appraisals may also raise heightened awareness about what can and should be learned from opportunity identification (Hatch and Dyer, 2004). In addition, a team-based design that encourages connectedness among individuals from across the organization can enable communication that allows the sharing, interpretation, integration, and institutionalization of knowledge to take place. Thus, connectedness exposes individuals to disparate pockets of knowledge across the firm which can act as a catalyst for learning (Crossan et al., 1999; Zahra et al., 1999; Kang and Snell, 2009).

The reduction of barriers between managers and employees, bringing employees into organizational problem-solving and decision-making, transferring tasks and responsibilities to employees, providing opportunities for personal initiative, and implementing employee suggestions offer additional organizational impetus beyond a developmental performance appraisal systems to further push individuals to learn from experience and improve their capabilities at corporate opportunity identification (Kang and Snell, 2009).

Some but not all of the structures and practiced described above may help with the organization's ability to benefit from tacit knowledge. Learning from experience has often been associated with tacit knowledge. While tacit knowledge has been associated with sustaining competitive advantage, it is difficult to share and transfer in order to combine it with existing knowledge inside or outside the firm (Galunic and Rodan, 1998; Haas and Hansen, 2005). Zollo and Winter (2002) argue that greater learning effectiveness may be achieved by focusing on knowledge articulation and codification as learning mechanisms. A team-based structure supports these mechanisms (Griffin et al., 2007). Important collective learning occurs when 
individuals express their opinions and beliefs, engage in constructive confrontations, and challenge each other's viewpoints (Argyris and Schön, 1978; Crossan et al., 1999). Articulation enhances awareness of the existence of knowledge, focuses on specifying the type and depth of new knowledge resulting from entrepreneurial activities, and crystallizes insights that have been gained (Zahra et al., 1999). Zollo and Winter (2002) argue that knowledge articulation may be achieved through collective discussions, debriefing sessions, and performance evaluation processes. An even higher level of cognitive effort is required when individuals codify their understanding in the form of written tools such as manuals, blueprints, decision support systems, project management software etc. This process of knowledge codification can improve the understanding of an experience even if learning is not the ultimate goal. For example, Zollo and Winter (2002: 342) point out that those individuals in the process of writing guidelines to improve execution of a complex task (e.g. the development of a new product) are more likely to achieve a higher degree of awareness and understanding of what makes a certain process succeed or fail, compared to telling "war stories” or discussing it in a debriefing session.

Lepak and Snell (1999) propose that the value of an organization's human capital base can be viewed as the ratio of strategic benefits obtainable from human capital relative to costs incurred. The impact of corporate opportunity identification on the value of the organization's human capital base via corporate opportunity identification likely depends on employees' motivation to learn and the quality of their learning. The quality of learning, however, is likely to be influenced by a number of organizational structures and processes. This might include rewards for new knowledge creation and learning as well as encouraging knowledge articulation and codification. The latter might be (at least partly) achieved by providing support 
and time to enable individuals to reflect on past experiences (successes and failures; see Shepherd et al., 2009 on the latter) as well as adopting a team-based design that increases the connectedness among people so that experiences and knowledge are shared. Based on the above discussion we propose the following:

Proposition 5: The increase in the quality of human capital resulting from experiences with corporate opportunity identification will be positively moderated by the extent to which organizational mechanisms designed to motivate learning and improve the quality of learning (such as knowledge articulation and codification) are in place.

\section{Conclusion}

Despite numerous scholars highlighting the importance of an organization's human capital, few have explicitly explored the relationship between human capital and corporate entrepreneurship. The purpose of this chapter was to develop a human capital framework for studying corporate opportunity identification. The approach taken is unique in that it develops an endogenous perspective to the analysis of corporate entrepreneurship and human capital. Such a perspective takes an organic view of firm development in that resources, processes and outcomes are reciprocal and interactive (Farjoun, 2002) and thereby appreciates the complexity of causal linkages. We build on and extend extant studies that have explored the antecedents of corporate entrepreneurship to include the role of human capital. This is based on the understanding that ultimately it is individuals that initiate entrepreneurial actions. Employees with superior level of human capital (especially entrepreneurship-specific 
and firm-specific human capital) may find themselves in a better position to identify entrepreneurial opportunities for the organization. We argue, however, that the firm's EO and certain organizational practices and structures may strengthen the relationship between human capital and corporate opportunity identification. An EO may act as a knowledge structure serving to act as a guide for human capital deployment. Further, various organizational practices and structures (e.g. cross-functional teams and rewards) may encourage employees to leverage and share the knowledge embedded in their human capital.

How organizational outcomes influence the resource base of the firm is a relatively unexplored dyadic relationship (Farjoun, 2002). In this chapter we have sought to address this void by arguing that experiences with corporate opportunity identification can result in the modification of the organization's human capital base. Experience with opportunity identification and exploitation has been associated with increases in entrepreneurship-specific human capital (Coff, 2005) as experience is converted into knowledge through learning. We argue, however, that in the absence of a set of intervening factors, individuals may be insufficiently motivated to learn and may be prone to biases and error when interpreting experience. Therefore, the design of reward systems and training schemes may result in greater increases in the value of human capital following experiences with corporate opportunity identification. In addition, following Zollo and Winter (2002), we argued that organizational processes geared toward knowledge articulation and codification may ensure that employees can achieve a deeper understanding of their experience, ensuring that learning is more reflective, valuable to future endeavours and not semi-automatic.

Future research may benefit from subjecting the framework presented in this chapter to empirical testing. To untangle the reciprocal nature of the relationships 
between human capital and opportunity identification, a longitudinal approach is recommended. Guidance can be taken from studies that have operationalized the concepts discussed in this chapter. For example, there are numerous studies that have operationalized human capital (cf. Gimeno et al., 1997; Ucbasaran et al., 2008; Unger et al., 2011). Further, Lepak and Snell (2002) offer means of measuring the value and uniqueness of an organization's human capital. With respect to opportunity identification, following the creativity literature (Amabile, 1990), respondents may be asked to indicate the number of opportunities they have identified in a given period. Alternatively, the number of patents filed may give an indication that the company believes a particular technology or innovation represents a commercial opportunity (e.g., Wadhwa and Kotha, 2006). Studying the number of opportunities identified / patents may be particularly useful because individuals who identify more opportunities may have more to choose from and thus are likely to exploit better quality opportunities (Ucbasaran et al., 2008).

Future researchers seeking to test our model need to consider the unit of analysis. It may be very difficult to collect information on the human capital of every single employee in the firm. A compromise may be to consider the human capital of middle managers. While entrepreneurial activity may be initiated from executive (Coombes et al., 2011) and operating levels, there appears to be some consensus that the middle layers of the management hierarchy are the locus of CE (Floyd and Wooldridge, 1999; Hornsby et al., 2002; Shimuzu, 2012; Garciá-Morales et al., 2014).

Two omissions from our framework may be noted. Given the scope of this chapter, there is an absence of discussion on opportunity exploitation and the role of the external environment. Future research may benefit from incorporating these concepts into our model. As intimated earlier, entrepreneurship scholars have 
emphasized the importance of opportunity identification and exploitation. While human capital may have important implications for the likelihood and nature of opportunity exploitation, different kinds of human capital may play different roles in the identification as compared to the exploitation of opportunities. For example, while entrepreneurship-specific human is likely to be crucial to opportunity identification, firm-specific and general human capital may be more important for opportunity exploitation (Choi and Shepherd, 2004; Kang and Snell, 2009). Future researchers might fruitfully distinguish between these two stages. The external environment has been highlighted as being an important factor influencing corporate entrepreneurship. In particular, corporate entrepreneurship has been found to be common and more beneficial in more dynamic, heterogeneous and hostile environments. Russell (1999) argues that dynamic and heterogeneous environments may offer more opportunities for firms to identify and exploit, while hostile environments may provide a stronger incentive for firms to pursue innovative activities as a source of competitive advantage. These environments may serve to motivate employees to leverage their human capital to identify opportunities but also motivate them to learn from their experience so as to develop their human capital for future rounds of entrepreneurial activity.

Our model has potentially important implications for managers / organizations in pursuit of competitive advantage through entrepreneurial activity. Theoretically there is strong foundation for assuming that human capital is central to entrepreneurial opportunity identification. Much of the organization's knowledge resides in its human capital (Hitt et al., 2001). Therefore, the selection, deployment and development of employees’ human capital are likely to be of significant importance to the firm (Lepak and Snell, 1999). Managers need to carefully consider the design of organizational 
structures and practices that can ensure that the firm maximizes the benefits from its human capital (e.g. rewards, communication systems, team-design etc.) (Kang and Snlee, 2009). Further, given that the value and uniqueness of human capital can erode overtime (Lepak and Snell, 1999), managers need to ensure that they nurture organizational human capital. In particular, by paying attention to knowledge articulation and codification, managers may ensure that employees learn more from organizational experiences than if left unattended. Though not discussed in this chapter due to space limitations, managers also need to acknowledge the relationship between human capital and social capital (Kor and Mesko, 2013). Human capital is often enhanced through the firm's social capital (Lepak and Snell, 1999; Kang and Snell, 2009). Adler and Kwon (2002) highlighted social capital's importance in a number of organizational activities including the creation of intellectual capital, learning, innovation and entrepreneurship. Unfortunately, it can be very difficult to empirically distinguish between human and social capital (Coff, 2005).

Overall, paying greater attention to the organization's human capital endowment is likely to have important implications for managers in pursuit of corporate entrepreneurship and scholars seeking to improve our understanding of these phenomena. 


\section{References}

Adler, P.S. and Kwon, S.-W. (2002). Social Capital: Prospects for a New Concept. Academy of Management Review, 27: 17-40.

Ajzen, I. (1991). The Theory of Planned Behavior. Organizational Behavior and Human Decision Processes, 50, 179-211.

Alvarez, SA. and Barney, J. (2007). Discovery and Creation: Alternative Theories of Entrepreneurial Action. Strategic Entrepreneurship Journal, 1: 11-26.

Amabile, T.M. (1990). Within You, Without You: The Social Psychology of Creativity, and Beyond. In M.A. Runco and R.S. Albert (eds.), Theories of Creativity. Sage Publications: Newbury Park, 61-91.

Argyris, C. and Schön, D.A. (1978). Organizational Learning: A Theory of Action Perspective. Reading, MA: Addison-Wesley.

Atuahene-Gima, K. and Ko, A. (2001). An Empirical Investigation of the Effect of Market Orientation and Entrepreneurship Orientation Alignment on Product Innovation. Organization Science, 12(1): 54-74.

Balkin, D., Markman, G. and Gomez-Mejia, L. (2000). Is CEO Pay in High Technology Forms Related to Innovation? Academy of Management Journal, 43(6): 1118-1129.

Barney, J. (1991). Firm Resources and Sustained Competitive Advantage. Journal of Management, 17: 99-129.

Barney, J. and Zajac, E.J. (1994). Competitive Organizational Behavior: Toward an Organizationally-Based Theory of Competitive Advantage. Strategic Management Journal, 15: 5-9.

Barringer, B.R. and Bluedorn, A.C. (1999). The Relationship between Corporate Entrepreneurship and Strategic Management. Strategic Management Journal, 20(5): 421-444.

Bates, T. (1995). Entrepreneur Human Capital Inputs and Small Business Longevity. The Review of Economics and Statistics, 72: 551-559.

Bazerman, M.H. (1990). Judgement in Managerial Decision Making, $2^{\text {nd }}$ edition. New York: John Wiley and Sons.

Becker, G.S. (1975). Human Capital. NBER: New York.

Becker, G.S. (1993). Nobel Lecture: The Economic Way of Looking at Behavior. The Journal of Political Economy, 101 (3): 385-409.

Bhagavatula, S., Elfring, T., van Tilburg, A., van de Bunt, G.G. (2010). How Social and Human Capital Influence Opportunity Recognition and Resource Mobilization in India's Handloom Industry. Journal of Business Venturing, 25(3): 245-260.

Bhuian, S.N., Menguc, B., and Bell, S.J. (2005). Just Entrepreneurial Enough: The Moderating Effect of Entrepreneurship on the Relationship between Market Orientation and Performance. Journal of Business Research, 58(1): 9-17.

Bird, B.J. (1992). The Operation of Intentions in Time: The Emergence of the New Venture. Entrepreneurship Theory and Practice, 17(1): 11-21.

Black, J. and Boal, K. (1994). Strategic Resources: Traits, Configurations and Paths to Sustainable Competitive Advantage. Strategic Management Journal, 15: 131-148.

Brazeal, D. (1993). Organizing for Internally Developed Corporate Ventures. Journal of Business Venturing, 8(1): 75-90.

Brown, T.E., Davidsson, P. and Wiklund, J. (2001). An Operationalization of Stevenson's Conceptualization of Entrepreneurship as Opportunity-Based Firm Behavior. Strategic Management Journal, 22(10): 953-968. 
Burgelman, R.A. (1983). A Process Model of Internal Corporate Venturing in the Diversified Major Firm. Administrative Science Quarterly, 28: 223-244.

Castanias, R.P. and Helfat, C.E. (1991). Managerial Resources and Rents, Journal of Management, 17 (1): 155-171.

Chandler, G.N., and Hanks, S.H. (1998). An Examination of the Substitutability of Founders Human and Financial Capital in Emerging Business Ventures. Journal of Business Venturing, 13(5): 353-369.

Chandler, G.N., Keller, C., and Lyon, D. (2000). Unravelling the Determinants and Consequences of an Innovation Supportive Culture. Entrepreneurship Theory and Practice, 25(1): 59-76.

Chaston, I., Sadler-Smith, E. (2012). Entrepreneurial cognition, entrepreneurial orientation and firm capability in the creative industries. British Journal of Management, 23 (2): 415-432.

Choi, Y.R and Shepherd, D.A. (2004). Entrepreneurs' Decisions to Exploit Opportunities. Journal of Management, 30: 377-395.

Coff, R. (1997). Human Assets and Management Dilemmas: Coping with hazards on the Road to Resource-Based Theory. Academy of Management Review, 22: 374402.

Coff, R. (2005). Entrepreneurial Human Capital. In Hitt, M. and Ireland, D. (Eds). Blackwell Encyclopedia of Management, Vol. III: 82-84.

Coleman, J.S. (1988). Social Capital in the Creation of Human Capital. American Journal of Sociology, 94: 95-120.

Coombes, S.M.T., Morris, M.H., Allen, J.A., Webb, J.W. (2011) Behavioral orientation of non-profit boards as a factor in entrepreneurial performance: does governance matter? Journal of Management studies, 48(4): 829-856.

Corbett, A.C. (2007). Learning Asymmetries and the Discovery of Entrepreneurial Opportunities. Journal of Business Venturing, 22(1): 97-118.

Covin, J.G. and Slevin, D. (1991). A Conceptual Model of Entrepreneurship as Firm Behavior. Entrepreneurship Theory and Practice, 16(1): 7-25.

Covin, J.G., Wales, W.J. (2012). The measurement of entrepreneurial orientation. Entrepreneurship Theory and Practice, 36 (4): 677-702.

Crossan, M., Lane, H., and White, R. (1999). An Organizational Learning Framework: From Intuition to Institution. Academy of Management Review, 24: 522-537.

Davidsson, P. and Honig, B. (2003). The Role of Social and Human Capital Among Nascent Entrepreneurs. Journal of Business Venturing, 18: 301-331.

De Clercq, D., Dimov, D., and Thongpapanl, N. (2010). The Moderating Impact of Internal Social Exchange Processes on the Entrepreneurial OrientationPerformance Relationship. Journal of Business Venturing, 25(1): 87-103.

De Luca, L.M. and Atuahene-Gima, K. (2007). Market Knowledge Dimensions and Cross-Functional Collaboration: Examining the Different Routes to Product Innovation Performance. Journal of Marketing, 70(1), 95-112.

Dess, G.G., Ireland, R.D., Zahra, S.A., Floyd, S., Janney, J. and Lane, P.J. (2003). Emerging Issues in Corporate Entrepreneurship. Journal of Management, 29(3): 351-378.

Dimov, D., and Shepherd, D. (2005). Human Capital Theory and Venture Capital Firms: Exploring "Home Runs" and "Strike Outs”. Journal of Business Venturing, 20: 1-21. 
Eddleston, K.A., Kellermanns, F.W., Zellweger, T.M. (2012). Exploring the entrepreneurial behaviour of family firms: does the stewardship perspective explain differences? Entrepreneurship Theory and Practice, 36 (2): 347-367.

Eisenberger, R., Fasolo, P., and Davis-LaMastro, V. (1990). Perceived Organizational Support and Employee Diligence, Commitment, and Innovation. Journal of Applied Psychology, 75(February): 51-59.

Engelen, A., Kube, H., Schmidt, S., Flatten, T.C. (2014). Entrepreneurial orientation in turbulent environments: the moderating role of absorptive capacity. Research Policy, 43(8): 1353-1369.

Farjoun, M. (2002). Towards an Organic Perspective on Strategy. Strategic Management Journal, 23: 561-594.

Field, S. (2001). Does Team Spirit Make Economic Sense? Observer, Summer: 5556.

Finkelstein, S. and Hambrick, D. (1996). Strategic Leadership. St. Paul: West.

Fiske, S.T. and Taylor, S.E. (1991) ( $2^{\text {nd }}$ edn.). Social Cognition. Singapore, McGraw Hill.

Floyd, S. and Wooldridge, B. (1999). Knowledge Creation and Social Networks in Corporate Entrepreneurship: The Renewal of Organizational Capability. Entrepreneurship Theory and Practice, 23(3): 123-143.

Gaglio, C.M. (1997). Opportunity Identification: Review, Critique and Suggested Research Directions. In J. A. Katz (eds.), Advances in Entrepreneurship, Firm Emergence and Growth, Vol. 3, JAI Press: Greenwich, CA, 119-138.

Gaglio, C.M. and Katz, J.A. (2001). The Psychological Basis of Opportunity Identification: Entrepreneurial Alertness. Small Business Economics, 16 (2): 95111.

Galunic, D.C. and Rodan, S. (1998). Resource Recombinations in the Firm: Knowledge Structures and the Potential for Schumpeterian Innovation. Strategic Management Journal, 19: 1193-1201.

Garciá-Morales, V.J., Bolívar-Ramos, M.T., Martín_Rojas, R. (2014). Technological variables and absorptive capacity's influence on performance through corporate entrepreneurship. Journal of Business Research, 67(7): 1468-1477.

Gimeno, J., Folta, T.B., Cooper, A.C., and Woo, C.Y. (1997). Survival of the Fittest? Entrepreneurial Human Capital and the Persistence of Underperforming Firms. Administrative Science Quarterly, 42(4): 750-783.

Grant, R. (1996). Toward a Knowledge-based Theory of the Firm. Strategic Management Journal, Winter Special Issue, 17: 109-122.

Grégoire, D.A., Barr, P.S., Shepherd, D.A. (2010). Cognitive processes of opportunity recognition: the role of structural alignment. Organization Science, 21 (2): 413431.

Grégoire, D.A., Shepherd D.A. (2011). Technology-market combination and the identification of entrepreneurial opportunities: an investigation of the opportunityindividual nexus. Academy of Management Journal, 55 (4): 753-785.

Gruber, M., MacMillan, I.C., Thompson J.D. (2012). From minds to markets how human capital endowments shape market opportunity identification of technology start-ups. Journal of management, 38 (5): 1421-1449.

Griffin, M.A., Neal, A., and Parker, S.K. (2007). A New Model of Work Role Performance Positive Behavior in Uncertain and Interdependent Contexts. Academy of Management Journal, 50: 327-347. 
Haas, M.R. and Hansen, M.T. (2005). When Using Knowledge can Hurt Performance: The Value of Organizational Capabilities in a Management Consulting Company. Strategic Management Journal, 26 (1): 1-24.

Hamel, G. and Prahalad, C. (1989). Strategic Intent. Harvard Business Review, MayJune, 63-79.

Hatch, N. and Dyer, J (2004). Human Capital and Learning as a Source of Sustainable Competitive Advantage, Strategic Management Journal, 25: 1155-1178.

Hayton, J.C. (2005). Promoting Corporate Entrepreneurship through Human Resource Management practices: A Review of Empirical Research. Human Resource Management Review, 15: 21-41.

Hitt, M. and Ireland, R.D. (2002). The Essence of Strategic Leadership: Managing Human and Social Capital. The Journal of Leadership and Organizational Studies, 9(1): 3-14.

Hitt, M., Bierman, L., Shimisu, K. and Kochhar, R. (2001). Direct and Moderating Effect of Human Capital on Strategy and Performance in professional Firms: A Resource-based Perspective. Academy of Management Journal, 44(1): 13-28.

Hornsby, J.S., Kuratko, D. and Montago, R. (1999). Perception of Internal Factors for Corporate Entrepreneurship: A Comparison of Canadian and U.S. Managers. Entrepreneurship Theory and Practice, 24(2): 9-24.

Hornsby, J.S., Kuratko, D.F., and Zahra, S.A. (2002). Middle Managers’ Perceptions of the Internal Environment for Corporate Entrepreneurship: Assessing a Measurement Scale. Journal of Business Venturing, 17: 253-273.

Hornsby, J.S., Kuratko, D.F., Shepherd, D.A., and Bott, J.P. (2009). Managers' Corporate Entrepreneurial Actions: Examining Perception and Position. Journal of Business Venturing, 24: 236-247.

Hostager, T., Neil, T., Decker, R. and Lorentz, R. (1998). Seeing Environmental Opportunities: Effects of Intrapreneurial Ability, Efficacy, Motivation and Desirability. Journal of Organizational Change, 11(1): 11-25.

Ireland, R. D., Covin, J.G., and Kuratko, D.F. (2009). Conceptualizing Corporate Entrepreneurship Strategy. Entrepreneurship Theory and Practice, 33(1): 19-46.

Ireland, R.D., Hitt, M.A., and Sirmon, D.G. (2003). A Model of Strategic Entrepreneurship: The Construct and its Dimensions. Journal of Management, 29(6), 963-989.

Ireland, R.D., Hitt, M., Camp, S. and Sexton, D. (2001). Integrating Entrepreneurship and Strategic Management Action to Create Firm Wealth. Academy of Management Executive, 15(1): 49-63.

Ireland, R.D., Kuratko, D.F., and Morris, M.H. (2006a). A Health Audit for Corporate Entrepreneurship: Innovation at all Levels, Part I. Journal of Business Strategy, 27(1): 10-17.

Ireland, R.D., Kuratko, D.F., and Morris, M.H. (2006b). A Health Audit for Corporate Entrepreneurship: Innovation at all Levels, Part II. Journal of Business Strategy, 27(2): 21-30.

Jansen, J.J.P., van den Bosch, F.A.J. and Volberda, H.W. (2006). Explorative Innovation, Exploitative Innovation, and Performance: Effects of Organizational Antecedents and Environmental Moderators. Management Science, 52(11): 16611674.

Jones, F., Morris, M. and Rockmore, W. (1995). HR Practices that Promote Entrepreneurship. HRMagazine, May, 86-91. 
Kaifeng, J., Lepak, D.P., Jia, J., Baek, J.C. (2012). How does human resource management influence organizational outcomes? A meta-analytic investigation of mediating mechanisms. Academy of Management Journal, 55(6): 1264-1294.

Kaish, S. and B. Gilad (1991). Characteristics of Opportunities Search of Entrepreneurs Versus Executives: Sources, Interests, General Alertness. Journal of Business Venturing, 6: 45-61.

Kang, S.-C. and Snell, S.A. (2009). Intellectual Capital Architectures and Ambidextrous Learning: A Framework for Human Resource Management. Journal of Management Studies, 46(1): 65-92.

Kanter, R.M. (1985). Supporting Innovation and Venture Development in Established Companies. Journal of Business Venturing, 1(1): 47-61.

Keh, H.T., Nguyen, T.T.M., and Ng, H.P. (2007). The Effects of Entrepreneurial Orientation and Marketing Information on the Performance of SMEs. Journal of Business Venturing, 22(4): 592-611.

Kelley, D.J., Peters, L., and O'Connor, G.C. (2009). Intra-Organizational Networking for Innovation-based Corporate Entrepreneurship. Journal of Business Venturing, 24(3): 221-235.

Kirzner, I. (1973). Competition \& Entrepreneurship, Chicago University Press: Chicago.

Kolb, D.A. (1984). Experiential Learning. Prentice-Hall, Englewood Cliffs, NJ.

Kor, Y.Y., Mesko, A. (2013). Dynamic managerial capabilities: configuration and orchestration of top executives' capabilities and the firm's dominant logic. Strategic Management Journal, 34(2): 233-244.

Kreiser P.M. (2011). Entrepreneurial orientation and organizational learning: the impact of network range and network closure. Entrepreneurship Theory and Practice, 35 (5): 1025-1050.

Krohmer, H., Homburg, C., and Workman J.P. (2002). Should Marketing be CrossFunctional? Conceptual Development and International Empirical Evidence. Journal of Business Research, 55: 451-465.

Krueger, N. (1993). Impact of Prior Entrepreneurial Exposure on Perceptions of New Venture Feasibility and Desirability. Entrepreneurship Theory and Practice, 18(1): 5-21.

Krueger, N. and Brazeal, D. (1994). Entrepreneurial Potential and Potential Entrepreneurs. Entrepreneurship Theory and Practice, 18(3): 91-104.

Krueger, N. (2000). The Cognitive Infrastructure of Opportunity Emergence. Entrepreneurship Theory and Practice, 24(3): 5-23.

Kuratko, D.F., Ireland, R.D., Covin, J.G., and Hornsby, J.S. (2005). A Model of Middle-level Managers' Entrepreneurial Behavior. Entrepreneurship Theory and Practice, 29(6): 699-716.

Lepak, D. and Snell, S. (1999). The Human Resource Architecture: Toward a Theory of Human Capital Allocation and Development. Academy of Management Review, 24(1): 31-48.

Lepak, D. and Snell, S. (2002). Examining the Human Resource Architecture: The Relationships among Human Capital, Employment, and Human Resource Configurations. Journal of Management, 28(4): 517-543.

Lichtenthaler, U. (2009). Absorptive Capacity, Environmental Turbulence, and the Complementarity of Organizational Learning Processes. Academy of Management Journal, 52(4): 822-846. 
Lichtenthaler, U. and Lichtenthaler, E. (2009). A Capability-Based Framework for Open Innovation: Complementing Absorptive Capacity. Journal of Management Studies, 46(8): 1315-1338.

Louis, M.R. and Sutton, R.I. (1991). Switching Cognitive Gears: From Habits of Mind to Active Thinking. Human Relations, 44 (1): 55-76.

Luchsinger, V. and Bagby, R. (1987). Entrepreneurship and Intrapreneurship: Behaviors, Comparisons and Contrasts. SAM Advanced Management Journal, 1013.

Lumpkin, G.T. and Dess, G.G. (1996). Clarifying the Entrepreneurial Orientation Construct and linking it to Performance. Academy of Management Review, 21: 135-172.

Lumpkin, G.T. and Dess, G.G. (2005). Entrepreneurial Orientation. In Hitt, M. and Ireland, D. (Eds). Blackwell Encyclopedia of Management, Vol. III: 104-107.

McCauley, C.D., Ruderman, M.N., Ohlott, P.J. and Morrow, J.E. (1994). Assessing the Developmental Components of Managerial Jobs. Journal of Applied Psychology, 79(4): 544-560.

McEvily, S. and Chakravarthy, B. (2002). The Persistence of Knowledge-Based Advantage: An Empirical Test for Product performance and Technological Knowledge. Strategic Management Journal, 23(4): 285-305.

Miller, D. (1983). The Correlates of Entrepreneurship in Three Types of Firms. Management Science, 29: 770-791.

Miller, D. and Lee, J. (2001). The People Make the Process: Commitment to Employees, Decision Making, and Performance. Journal of Management, 27: 163-189.

Miller, K.D. (2002). Knowledge Inventories and Managerial Myopia. Strategic Management Journal, 23: 689-706.

Minbaeva, D., Pedersen, T., Björkman, I., Fey, C.F. and Park, H.J. (2003). MNC Knowledge Transfer, Subsidiary Absorptive Capacity, and HRM. Journal of International Business Studies, 34: 586-599.

Mincer, J. (1974). Schooling, Experience and Earnings., New York: Columbia University Press.

Mitchell, R.K., Busenitz, L., Lant, T., McDougall, P., Morse, E. A., and Smith, J. B. (2002). Toward a Theory of Entrepreneurial Cognition: Rethinking the People Side of Entrepreneurship Research. Entrepreneurship: Theory \& Practice, 27(2): 93-105.

Monsen, E., Patzelt, H., Saxton, T. (2010). Beyond simple utility: incentive design and trade-offs for corporate employee-entrepreneurs. Entrepreneurship Theory and Practice, 34(1): 105-130.

Morris, M.H., Kuratko, D.F., and Covin, J.G. (2008). Corporate Entrepreneurship and Innovation. Cincinnati, $\mathrm{OH}$ : Thomson/SouthWestern Publishers.

Morrison, E.W. and Phelps, C.C. (1999). Taking Charge at Work: Extra-role Efforts to Initiate Workplace Change. Academy of Management Journal, 42: 403-419.

Nahapiet, J. and Ghoshal, S. (1996). Social Capital, Intellectual Capital and the Organizational Advantage. Academy of Management Review, 23: 242-266.

Narayanan, V.K., Yang, Y. and Zahra, S.A. (2009). Corporate Venturing and Value Creation: A Review and Proposed Framework. Research Policy, 38: 58-76.

Neale, M.A. and Northcraft, G.B. (1989). Experience, Expertise and Decision Bias in Negotiation: The Role of Strategic Conceptualization. In B. Sheppard and R. Lewicki (Eds.), Research on Negotiation in Organizations, Vol.: 2. Greenwich, Conn.: JAI Press. 
Nonaka, I. and Takeuchi, H. (1995). The Knowledge-Creating Company: How Japanese Companies Create the Dynamics of Innovation. New York: Oxford University Press.

Pérez-Luño, A., Wiklund, J., Cabrera J.V. (2011). The dual nature of innovative activity: how entrepreneurial orientation influences innovation generation and adoption. Entrepreneurship Theory and Practice, 26 (5): 555-571.

Pfeffer, J. (1994). Competitive Advantage Through People. Boston: Harvard Business School Press.

Phan, P.H., Wright, M., Ucbasaran, D. and Tan, W-L. (2009). Corporate Entrepreneurship: Current Research and Future Directions. Journal of Business Venturing, 24: 197-205.

Ployhart, R.E., Moliterno T.P. (2011). Emergence of the human capital resource: a multilevel model. Academy of management review, 36 (1): 127-150.

Ployhart, R.E., Nyberg, A.J., Reilly, G., Maltarich, M.A., (2014). Human capital is dead, long live human capital resources. Journal of Management, 40(2): 371-398.

Ployhart, R.E., Van Iddekinge C.H., Mackenzie, W.I. (2011) Acquiring and developing human capital in service contexts: the interconnectedness of human capital resources. Academy of Management Journal, 54(2): 353-368.

Real, J.C., Roldán J.L., Leal, L. (2014). From entrepreneurial orientation and learning orientation to business performance: analysing the mediating role of organizational learning and the moderating effects of organizational size. British Journal of Management, 25 (2): 186-208.

Russell, R.D. (1999). Developing a Process Model of Intrapreneurial Systems: A Cognitive Mapping Process. Entrepreneurship Theory and Practice, 23(3): 65-84.

Saeed, S., Yousafzai, S.Y., Engelen, A. (2014). On cultural and macroeconomic contingencies of the entrepreneurial orientation-performance relationship. Entrepreneurship Theory and Practice, 38(2): 255-290.

Sarasvathy, S. (2008). Effectuation: Elements of Entrepreneurial Expertise. Northampton, MA: Edward Elgar.

Sarin, S. and Mahajan, V. (2001). The Effect of Reward Structures on the Performance of Cross-Functional Product Development Teams. Journal of Marketing, 65 (2): 35-53.

Simsek, Z., Heavey, C. (2011). The mediating role of knowledge-based capital for corporate entrepreneurship effects on performance: a study of small- to mediumsized firms. Strategic Entrepreneurship Journal, 5 (1): 81-100.

Schumpeter, J. (1934). The Theory of Economic Development. OUP: Oxford.

Sethi, R., Smith, D.C., and Park, C.W. (2001). Cross-Functional Product Development Teams, Creativity, and the Innovativeness of New Consumer Products. Journal of Marketing Research, 38: 73-85.

Shane, S. (2000). Prior Knowledge and the Discovery of Entrepreneurial Opportunities. Organization Science, 11: 448-469.

Shane, S. and Venkataraman, S. (2000). The Promise of Entrepreneurship as a Field of Research. Academy of Management Review, 25, 217-226.

Sharma, P. and Chrisman, J. (1999). Toward a Reconciliation of the Definitional Issues in the Field of Corporate Entrepreneurship. Entrepreneurship Theory and Practice, 23(3): 11-27.

Shepherd, D.A. and DeTienne, D.R. (2005). Prior Knowledge, Potential Financial Reward, and Opportunity Identification. Entrepreneurship Theory and Practice, 29(1): 91-112. 
Shepherd, D.A., McMullen, J.S., and Jennings, P.D. (2007). The Formation of Opportunity Beliefs: Overcoming Ignorance and Reducing Doubt. Strategic Entrepreneurship Journal, 1: 75-95.

Sherer, P. (1995). Leveraging Human Assets in Law Firms: Human Capital structures and Organizational Capabilities. Industrial and Labor Relations Review, 48: 671691.

Shimuzu, K. (2012). Risks of corporate entrepreneurship: autonomy and agency issues. Organization Science, 23(1): 194-206.

Shook, C.L., Priem, R.L., and McGee, J.E. (2003). Venture Creation and the Enterprising Individual: A Review and Synthesis. Journal of Management, 29(3): 379-399.

Snell, S. and Dean, J.W. (1992). Integrated Manufacturing and Human Resources Management: A Human Capital perspective. Academy of Management Journal, 35: 467-504.

Stam, W. and Elfring, T. (2008). Entrepreneurial Orientation and New Venture Performance: The Moderating Role of Intra- and Extraindustry Social Capital. Academy of Management Journal, 51(1): 97-111.

Stewart, T.A. (1997). Intellectual Capital: The New wealth of Organizations. New York: Doubleday / Currency.

Stopford, J.M. and Baden-Fuller, C.W.F. (1994). Creating Corporate Entrepreneurship. Strategic Management Journal, 15: 521-536.

Sykes, H.B. (1992). Incentive Compensation for Corporate Venture Personnel. Journal of Business Venturing, 7: 253-265.

Ucbasaran, D., Westhead, P. and Wright, M. (2008). Opportunity Identification and Pursuit: Does an Entrepreneur's Human Capital Matter? Small Business Economics, 30: 153-173.

Ucbasaran, D., Westhead, P. and Wright, M. (2009). The Extent and nature of Opportunity Identification by Repeat Entrepreneurs, Journal of Business Venturing, 24: 99-115.

Unger, J.M., Rauch, A., Frese, M., and Rosenbusch, N. (2011). Human Capital and Entrepreneurial Success: A Meta-Analytical Review. Journal of Business Venturing, 26 (3): 341-358.

Wadhwa, A. And Kotha, S. (2006). Knowledge Creation through External Venturing: Evidence from the Telecommunications Equipment Manufacturing Industry. Academy of Management Journal, 49: 819-835.

Wales, W., Monsen, E., McKelvie, A. (2011). The organizational pervasiveness of entrepreneurial orientation. Entrepreneurship Theory and Practice, 35 (5): 895923.

Wales, W.J., Parida, V., Patel, P.C., (2013). Too much of a good thing? Absorptive capacity, firm performance and the moderating role of entrepreneurial orientation. Strategic Management Journal, 34(5): 622-633.

Walsh, J.P. (1995). Managerial and Organizational Cognition: Notes from a Trip Down Memory Lane. Organization Science, 6 (3): 280-321.

Wiklund, J. and Shepherd, D. (2003). Knowledge-Based Resources, Entrepreneurial Orientation, and the Performance of Small and Medium-Sized Businesses. Strategic Management Journal, 24: 1307-1314.

Witt, U. (1998). Imagination and Leadership - The Neglected Dimension of an Evolutionary Theory of the Firm. Journal of Economic Behavior and Organization, 35, 161-177. 
Wright, P., Dunford, B. and Snell, S. (2001). Human Resources and the ResourceBased View of the Firm. Journal of Management, 27(6): 701-722.

Zahra, S.A. (1993). A Conceptual Model of Entrepreneurship as Firm Behavior. Entrepreneurship Theory and Practice, 14(4): 5-21.

Zahra, S.A. (2008). The Virtuous Cycle of Discovery and Creation of Entrepreneurial Opportunities. Strategic Entrepreneurship Journal, 2: 243-257.

Zahra, S.A. and Jennings, D. and Kuratko, D. (1999). The Antecedents and Consequences of Firm-level Entrepreneurship: The State of the Field. Entrepreneurship Theory and Practice, 24(2): 45-65.

Zahra, S.A., Filatotchev, I., and Wright, M. (2009). How Do Threshold Firms Sustain Corporate Entrepreneurship? The Role of Boards and Absorptive Capacity. Journal of Business Venturing, 24(3): 248-260.

Zahra, S.A., Nielsen, A. and Bogner, W. (1999). Corporate Entrepreneurship, Knowledge, and Competence Development. Entrepreneurship Theory and Development, 23(3): 169-189.

Zakay, D., Ellis, S. and Shevalsky, M. (2004). Outcome Value and Early Warning Indications as determinants of Willingness to Learn from Experience. Experimental Psychology, 51(2): 150-157.

Zhao, Y., Li, Y., Chen, L.B. (2011). Entrepreneurial orientation, organizational learning and performance; evidence from China. Entrepreneurship Theory and Practice, 35 (2), 293-317.

Zollo, M. and Winter, S.G. (2002). Deliberate Learning and the Evolution of Dynamic Capabilities. Organization Science, 13(3): 339-351. 
Figure 1. A Human Capital Framework of Corporate Opportunity Identification

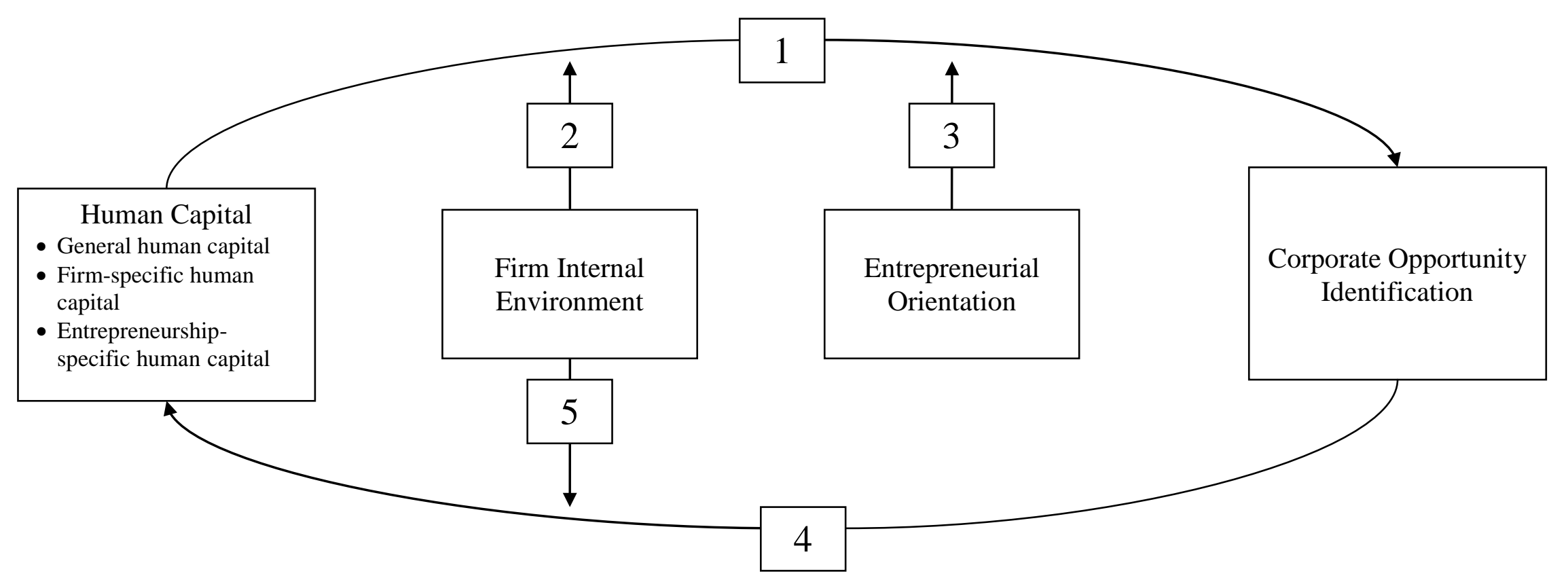


Figure 2. Lead Structures and Processes Influencing the Internal Environment in which Human Capital and Corporate Entrepreneurship can be Leveraged

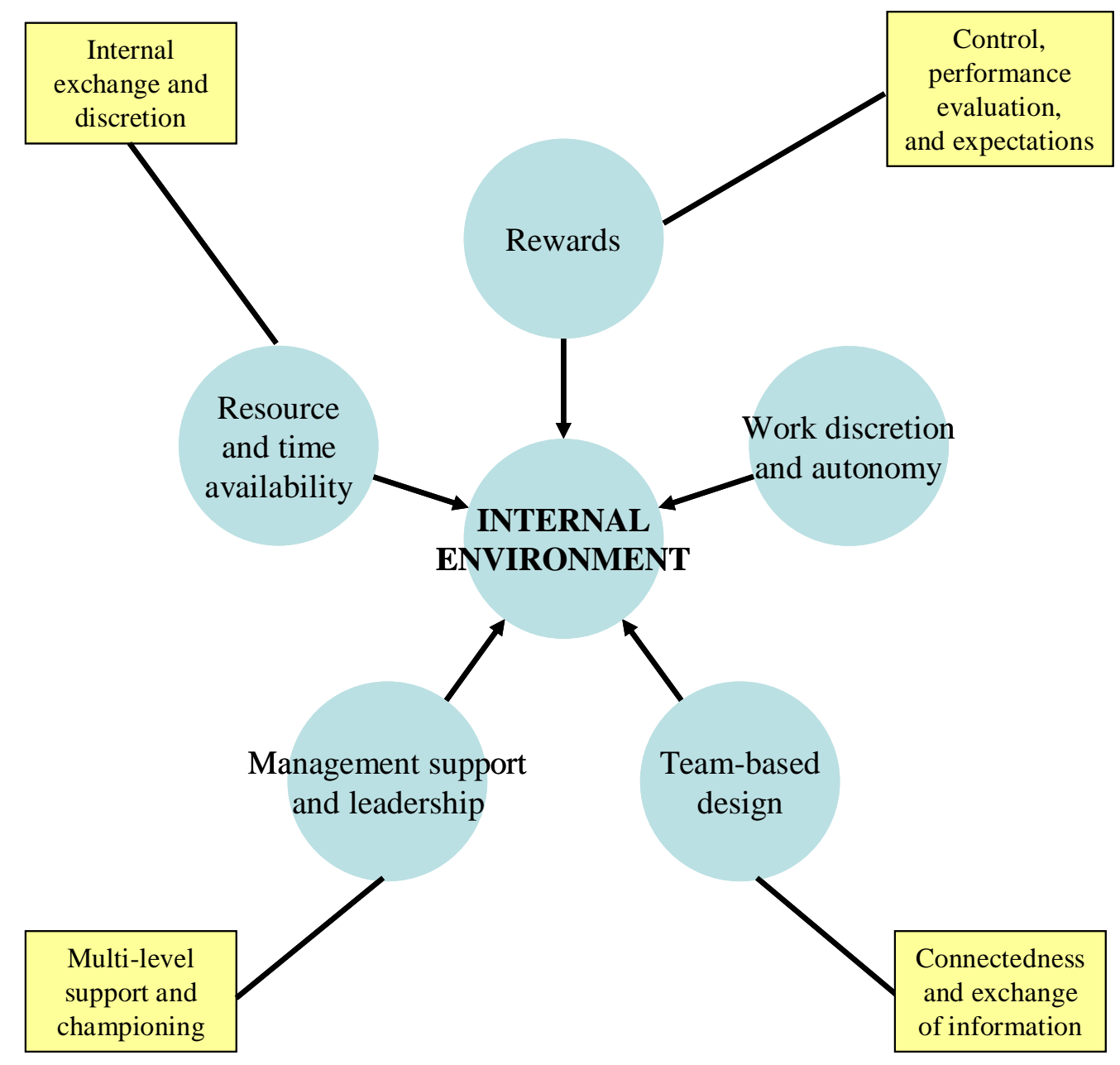

